Report of Conference

XL. National Conference on Teaching

Mathematics, Physics and Computer

Sciences
August 22 - 24, 2016
Székesfehérvár, Hungary

The XL. National Conference on Teaching Mathematics, Physics and Computer Sciences (MAFIOK) was held in Székesfehérvár, Hungary between 22 and 24 August, 2016 at the Alba Regia Technical Faculty of Óbuda University. For the three-day event, more than 80 persons were registered and more than 40 lectures were given. The fortieth anniversary scientific conference was designed for researchers and teachers in mathematics, physics and informatics to promote modern and efficient education in higher education, and through poster presentations and personal meetings to exchange experience. The opening ceremony of the conference followed by the three plenary lectures took place at the ceremonial hall of the Town Hall. József Gyulai emeritus professor (BME) speculated whether the science modeled on Gordon Moore's "law" will be able to grow exponentially in other areas, at miniature "component" and at the information level. He talked about the micro-world where science differentiated, but nowadays stepped to the nano world, where physics, chemistry, biology will be re-integrated. Professor László Tóth (University of Miskolc, Bay Zoltán Research Institute) interpreted our time as a revolution in materials science, which is expected to replace the computer revolution. Based on his calculations, this will happen in 2025, and based on the hypothesis of nanotechnology and materials science knowledge revolution will end in 2081. Prof. Gábor Szabó, Rector of the University of Szeged - citing specific examples - talked about what and how to teach or even not to 
teach the students. The second and third day was divided into sections: mathematics, physics, informatics and specific topics of education (see abstarcts). The conference was closed again in three plenary lectures. Mihály Klincsik, professor at the University of Pécs talked about the modern mathematical modeling. The solutions of a reaction-diffusion system describes the natural patterns, which is unravels the morphogenesis, as well as plant and animal patterns (zebra stripes, leopard patches ...). Szaniszló Bérczi (ELTE) compared technological flows to the natural, e.g. geological and environmental flows in his lecture. Professor Ms. Valéria Csépe (Academy of Natural Sciences Brain Research Center) taught about what and when can be teach to schoolchildren. Her ideas was supported by the results of the latest brain research experiments.

This report contains the abstract of lectures presented at the conference, grouped by plenary sessions and areas of interest: mathematics, physics and computer sciences, in the order in which it was presented in its own group.

\section{Abstracts from plenary lectures}

József Gyulai (Hung. Acad. Sci. EK MFA and BME Faculty of Elec. Eng. and Inf.): Moore's Law of Micro- and Nanotechnology - Effect of Market Force on Interface of Physics, Chemistry, and Information Technology

In my previous talk on this conference (2009), microelectronics was quoted as Cinderella of sciences, because with rapid development of applications detailed results, demands of production technologies remained hidden. Development of microelectronics is often characterized with the so-called "Moore's Law", which has not started as "law", only as early observation by Gordon Moore, published in a paper just fifty one year ago. Moore had noticed that technical development of production of semiconductor integrated circuits is exponential, i.e., in every other year twice as much components were produced on a single chip by the integrated circuit industry, chips in quality corresponding to market demands. Think, in the first hand on system reliability. The present talk gives an overview on this miniaturization, to achieve more and more complex functions. Leading to systems, which aim at even biological, medical goals.

The talk will give examples what kind of demands, including market-driven demands, coupled difficulties were overcome of device physics. Solutions of which needed up-to-date results in physics, metallurgy, optics, chemistry - not only of solid state chemistry, but of organic, and polymer chemistry, too. Results of the 
topic represent probably the most brilliant example of teaching "science". How the results integrate into a single industrial know-how. An integration, where results of individual scientific topics, physics, chemistry, etc., even biology can be individually recognized. It is sad that this process has never got real accent in present day elementary or high school curricula. It is true that the topic is approaching peak point of its development gaussian, but, to our conviction, still decades are to come before fully new methods, principles are needed to meet demands of information technology.

SzANiszló BÉRCzI (Eötvös Loránd University, Budapest, Hungary): Synthesis: Concepts on the Overview of the Environmental Science from Aspects of Mathematics, Physics, and Informatics

Education of natural sciences is analytically oriented. Digging deep in the details it forgets to synthesize, however, modern life requests the integration of partial knowledge. Our MSc synthesis course in environmental science is focusing on this modern request. The course begins to study the basic phenomena in nature but on the fundaments of common principles. One of them is the description of the environmental changes by the stages (by the phases) of the processes. This formulation unifies the methods of various disciplines by its simplicity. Similarly there is a common principle of decomposition and rebuilding. This principle focuses on the analysis of systems. The principle of decomposition and rebuilding applies the counterpart processes of destruction and building up in engineering and natural systems, too. Our new approach produces structural hierarchy, joint description of prcesses running parallel, woven processes of technologies and environmental streams.

\section{Mathematics}

Antal Joós (Szent István University Ybl Miklós Faculty, Department of Mathematics and Informatics, Budapest, Hungary): A New Nontriangulable Polyhedron

Triangulations of 3-dimensional polyhedron are partitions of the polyhedron with tetrahedra in a face-to-face fashion without introducing new vertices. We give a new family of nontriangulable polyhedra. 
Dr. GÁbor Horváth (BGE PSZK, Budapest, Hungary): Some Geometrical Inequality - a Case Study

We will prove some known inequalities concerning triangles such that the proofs will differ somewhat from the proofs published by other authors. We will discuss the Erdős's Mordell inequality, Oppenheim's inequality and Hadwiger Finsler's inequality.

István BÉLA Kovács (BGE PSZK Budapest, Hungary): Ideas Emerging From Teaching the Lagrange Interpolation Polynomial

We show first how we have transformed teaching Lagrange interpolation making better use of the concepts of linear algebra in a course of numerical methods for informatics students. We introduce an application that can be taught in the course and present an elegant treatment of the topic.

Attila Tóth, Antal CsÁky (UKF Nitra, Slovakia): Understanding Calculus - The Shortest Way

The submitted contribution emphasizes the importance of teaching fundamentals of differential calculus at secondary schools. Students can receive adequate basics of differential calculus in as few as 5-6 motivational lessons, and that would be sufficient background for their future university studies. In this study we present several tasks which can catch the students' interest in differential calculus and at the same time show its application in various specialized areas.

Dr. Zsuzsanna GÖNYE (Nyugat-magyarországi Egyetem, Szombathely, Hungary): Futureproofing Mathematics Education

Based on the report The Future of Jobs of the World Economic Forum the workforce will dramatically change in the next few years. What skills do we need in our jobs in just a few years? The report shows, that the number of jobs in the area of mathematics and computer science will rise, and there are many other fields in which mathematics will play a key role. This is an area in which we, humans still succeed machines. Nevertheless teaching this subject has its own set of problems in many countries. Our results on the international tests are continuously declining. Why is teaching mathematics more successful in Singapore, who is on the top of the chart in these tests? Four American schools started a pilot program to adopt the "Singapore math". What can we learn from this experiment? 
EszTer Árokszállási (Paksi Vak Bottyán Gimnázium, Paks, Hungary):

How Can We Help our Average Abilities, and Maths Gifted Students at the Same Time? (Development of the Combinatorical Thinking in Secondary School)

The combinatorics of teaching has a long tradition in Hungary. Despite this, we get such feedbacks from universities that learners do not know the combinatorics tasks. In my research, I am looking for answers to classroom conditions to what could be the reason and how can I help my students. I use the theoretical background of Bruner's representational levels with medium teacher's guide. Students receive immediate and continuous feedbacks about their work. I take into account the cognitive load theory and the results of the latest learning theories also. In my paper, I would like to talk about how to develop a math gifted, and average abilities student, in the last two years. This presentation based on of "ProMath 2015, September 03rd to September 05th, 2015 University of Halle-Wittenberg, Faculty of Educational Sciences" and "MIDK2016. Bratislava, January 23, 2016", methodological presentations at conferences. I present the most recent research work, which is carried out in 2016 between May and June.

\section{István Talata (SZIE, Budapest Hungary): Geodesic Polyhedrons}

A geodesic polyhedron is a triangulation of a Platonic solid or other convex polyhedron to produce a close approximation to a sphere. A geodesic polyhedron of order $\mathrm{n}$ can be defined recursively, for every $n \geq 1$, by creating it as a refined triangulation of a geodesic polyhedron of order $(n-1)$. Geodesic domes were invented by Walther Bauersfeld in 1923, but geodesic domes and geodesic polyhedra, respectively, were popularized by Buckminster Fuller in the 1960's. In Balatonboglár, the metal structure of the Spherical Lookout is the edge framework of a geodesic polyhedron. It is one of the topics in the course "Space Geometry with Computers" at Ybl Faculty of Szent István University to model geodesic polyhedra with different softwares (AutoCAD, Cabri 3D, GeoGebra), and because we choose among those polyhedra those ones that have high level of symmetry, therefore geometric transformations can be used to construct all of the many faces of such polyhedra. This helps architecture students to have a better understanding of polyhedra and geometric transformations, and to develop their space vision. 
Anna Klingné Takács (BGE, Budapest, Hungary): Education of Bivariable Functions with Geogebra

In addition to traditional calculus, Economics students learn the basic theory of multivariate functions. We teach only finding local extremal values and constructing the equations of level curves, since have few classes on the topic. We use traditional methods, and computerized methods for illustration, comprehension. According to Bruner's theory illustration is important in the teaching-learning process at all times. GeoGebra is a proper tool for the 3D illustration of simple two variable functions. Our presentation introduces an example for this.

Edit LÁzÁr (Budapest Business School, Budapest, Hungary): Students' Motivation at the High Education

The structure of high education will change. Only will have money reasearches that have connection with $\mathrm{R}+\mathrm{D}$. So the subjects tought by universities will have to be closer to real life. Students also want changes. It was a research about the future of economic high education in 2050 with students and teachers by the Reseach Center of BBS. Students think high education will change: universities will be more connected with each other; will be personal teaching and online, too; students will be more motivated because their knowledge level will be similar; etc. The experience of the author if students understand the connetions between a subject and real life they can accept, understand, learn it easier, they will have more success in it. In this article the author wants to show two working methods to motivate students in the high education. The first one (named "Crest-game" by the author) was used during the teaching of theory of decision at the university of BBS/CFA by the author, the second was tought by Judith Pálfi giving lessons (lectures and labours) CAD and technical documentation writting subjects at the University of Óbuda. (The second method is written by the allowance of Judith Pálfi. Author will mention it as Palfi-method.) Crest-game is a good method to form groups at the beginning of the semester and work in pairs or in groups of 4-6. The method: everybody has a piece of paper of A4 and divide it for 4 equal parts by 2 perpendicular axis (horizontally and verically by the middle of the paper). You can only DRAW! You have to draw the most beautiful experience of your life at the top of the left, below: the most beautiful experience of last year; at the top of the right: I am good at... / I do this well... and below: I want to do this in the future. At the end you have to organize couples and people in pairs introduce oneselfe. Then they form groups of 4-6 (maximum 7) people and introduce the other member of the original couple to the others. Palfi-method: At the beginning of the semester they form couples. The teacher give all the materials avaible 
to students. Each couple has to choose one of the topics. They will give an oral presentation of the topic in ten minutes. In this presentation they need use topic material; an example (or more) taken by real life; humor and they have to put 5 specific questions about the topic (with answers). These questions will be later the test-questions at the end of the semester. Other students have to evaluate the presentation by given viewpoints. Students have to give points to their mates for the work. At the end they check everything and the teacher also give some advices. With the Palfi-method students will have a saved opportunity to speak and become a performer before the final exam of graduation (for a lot of student it is very difficult to give an oral conference with audience), and understand better the subject.

\section{Physics}

Dr Dorottya Sebestyén (Óbuda University, Budapest, Hungary): From Archimedes' Screw to the Nuclear Energy - Energetics in the History of Physics

At the Óbuda University the Physics as a subject contains knowledge from the mechanics to the nuclear physics helping to establish the professional knowledge of the electrical engineering students. "The cultural history of physics" also serves this purpose. Looking over the history of physics, one can find the interesting conclusion that at the same time it is the history of the applications, and transformations of energy, speaking about the mechanics, optics, thermodynamics, electricity or nuclear physics. This presentation intends to produces some examples from the history of physics from the mentioned viewpoint.

Éva Mária OlÁH (Bálint Márton Általános és Középiskola, Törökbálint, Hungary): How to Build Muon-detector involving Students and Teachers

There is little time for teaching particle physics in secondary schools, although familiarizing students with one of the leading branches of physics of our time is an interesting and very important task. For years several high school students have had chance to widen their knowledge using a research based learning method. During this the students had a chance to join the work of REGARD (RMKI ELTE GAseous detector Research and Development) at the Wigner Research Centre for Physics and have had the opportunity to carry out measurements using multiwire chambers designed and assembled by themselves. By stacking the chambers above each other and using strands of LED lights, the direction of the incoming particles can be made visible. Within the framework of CERN's teacher course, physics 
teachers can get familiar with the programme and build the model developed by the researchers and students.

Csilla FülÖP*, Éva Csilla Kiss** (*Madách Imre Gimnázium, Budapest, ELTE TTK Fizika Tanítása Doktori Iskola, ${ }^{* *}$ Neumann János Számítástechnikai Szakközépiskolája, Budapest, Hungary): Projects for Students Teaching the Law of the Radioactive Decay

The method called the students' measuring project focuses on the active participation of the students. We used this didactical tool also in the preparatory period of the experiment to teach some classical laws of nature. We used this method to introduce one of the most problematic tasks in methodology, the law of radioactive decay. The close of the experiment was a competence based delayed survey for the groups participating in the testing and also for the control groups. Based on the evaluation of these we can conclude that the method is worthy to be present among the recommended tool in physics methodology. We report on the didactical and methodological background of our teaching experiment and the details of the implementation. Based on these we recommend our colleagues the "students' measuring project" method.

LÁSzlónÉ LEITNER (SZIKGÁIKOAMI, Nyíregyháza, ELTE PhD student, Budapest, Hungary): Appearance of Network Research'Elements During the Teaching of Physics

Difficulties of teaching of physics besides keeping the students' interest is maintaining the scientific way of thinking, and evolving the openness towards the technological development. An average student over the classroom environment increase varied rela-tions and maintain, he lives in a society, where he meets the economy, the commerce, the entertainment interweaving network. The conscious display of the science of network's elements in physics lessons science erudition we ensure the development of a network of competence as well. During the research to NAT 2012 related in "Kerettanterv-B változat Fizika" links can be found and I collected them. Each option that appearing in science-related network are themes, I grouped on the basis of analytical and relational criteria. In teaching of physics nor extra time, or restructuring, or material prejudice to the application needed, but it contributes to if the network positive or negative elements appears, students could use and apply them correctly beyond the study period too. 
Dr. ERvin RÁcz (Óbuda University, Budapest, Hungary): About Educational and Methodological Problems in Physics as Foundation Object at Engineering Informatics Bs.C. Program

Physics is one of the foundation object in engineering informatics B.Sc. program at John von Neumann Faculty at the Óbuda University. Admitted new students study Physics during the very first semester of their university life. Physics education has two main parts: lecture and practice. Aims of Physics education are: improving problem-solving thinking, widening general scientific horizon, checking, correcting and improving of numeracy skills, which have been formed out in the high school. Headcount of the newly admitted students is about 300 persons in every year. 50 percent of the mentioned headcount can successfully meet the requirements of Physics at the end of the semester. Other students cannot pass Physics on time. This publication presents the experienced problems and questions related to the differences of previous experiences and shortcomings of the students, studying attitudes of students, and experienced problems regarding to the Physics education.

DR. GyÖRGy HudobA (Óbuda University Alba Regia Technical Faculty, Székesfehérvár, Hungary): EXCEL-Physics - Exoplanet Transit Light Curve Simulation

Searching for exoplanets is a hot topic of astronomical research. At the moment of writing more than two thousand exoplanets were registered. Most of them was discovered by analyzing the stellar light curve analysis, by the so called occultation, or transit method. When the dark planet moves in front of the bright stellar disc, the brightness of the star diminishes a little bit. The shape of the light curve, which depends on many parameters, does not need sophisticated programs, like Maltlab, Wolfram Mathematica or something like these, but can be simulated by a simple spreadsheet, like Excel.

\section{Informatics}

Teréz Nemes*, Zoltán Süle**, Ákos DÁvid ${ }^{* *}$ ( ${ }^{*}$ Department of Methodology of Budapest Business School Budapest, Hungary, ${ }^{* *}$ Faculty of Information Technology of University of Pannonia, Veszprém, Hungary): P-Graph Methodology an Efficient Approach for Optimizing Computer Systems

In recent years IT experts have encountered a continuously rising number of security events in computer systems. Due to the evolution of various types of 
cyber-attacks, designing an adaptive defense becomes challenging. The two fundamental elements of computer networks are robustness and the number of known vulnerabilities in the system. Measuring the level of security becomes even more demanding, but currently there is no objective method to do this automatically. The available measuring methods are usually subjective and are based on the surveying of system operators. Our aim is to design an objective definition for security level that is based on the topology provided by the operators. We provide an algorithmic method to calculate this value. This gives the optimization of the current architecture complying financial constraints. This method is used for measuring the robustness and vulnerability of computer systems. The mathematical background of our method is based on the P-graph methodology that has been used for modelling various engineering systems, as well as business processes and supply-chains. In this paper, we examine the security of computer systems with P-graph by transforming the current architecture topology given by a typical diagram representation into a $\mathrm{P}$-graph model.

JÁnos Katona (SZIE Budapest, Hungary): Online Computer Algebra Systems - a Comparison

We know a lot of Computer Algebra System (CAS) applications. Among other things, they are useful for studying and teaching mathematics. In this article we compare some typical CAS software. All of them are free, online and suitable to use in higher education.

LEvente RÁdAi (Óbuda University, Alba Regia Technical Faculty, Székesfehérvár, Hungary): Online Courses in Teaching ERP Systems

In previous years, a lot of online courses were developed in the field of ERP systems. There are quite a lot example for courses created by certain software developers and some courses were created by universities. The article collects the applied methods, course techniques and elements and try to evaluate, how these courses reimagine the learning methods of ERP systems. The other related issue is the ERP training system for learning, which is not always available for the students because of financial reasons. Is it necessary or can be substituted by cheaper solutions?

LEVEnte RÁdAi (Óbuda University, Alba Regia Technical Faculty, Székesfehérvár, Hungary): Memory-resident Business Informatic Solutions in the Education

Since 2011, in-memory application for on-line analytical processing functions as executive and management information systems are available. From last years 
for transaction processing functions, as well. As the top of ERP specialization in IT enginering bachelor program, the subject of management information system can apply these systems in the practical training. Some related publications are written about deeper examinations of in-memory OLTP and OLAP appcialtions in the Engineering Institute of Obuda University Alba Regia Technical Faculty, Székesfehérvár. But can they applied at ERP subjects, as well or not? What are the prerequisites in education methodology aspect? Good answers can reform the practical part of ERP specialization of IT engineering BSc program.

LÁszló Gimesi*, Ildikó Jenák* , PÉter Surányi** (*University of Pécs, Hungary, ${ }^{* *}$ Pécsi Árpád Fejedelem Gimnázium és Általános Iskola, Pécs, Hungary): Possibilities and Expectations in Teaching IT in Hungary

Even though nearly 20 thousand IT worker is absent from Hungarian economy, only 2500-3000 students acquire qualification in IT every year. But professionals teaching informatics are missing from public and higher education too. Also, we should not forget that ordinary people's digital competency has severely fallen off from the world which is increasingly progressing towards a fully digitalised society. Our research aims to assess the state of today's informatics training, map such possibilities and methods that could foster a major positive change. We compare regulations of National Curriculum and Curriculum Framework to international trends and needs. With presenting our results we would like to contribute to develop IT teaching and IT specialist training and facilitating an increase in general IT literacy.

Éva Hajnal, Dezső Hatalyák (Óbuda University Alba Regia Technical Faculty, Székesfehérvár, Hungary): Alba Regia IT Competition as a Talent Management Tool

The history of this competition of the Alba Regia Technical Faculty comes back to 5 years. It is a traditional competition in the field of IT skills, but it is implemented in e-learning system. The role of this competition is to help the preparation to the enhanced IT exam at the end of the secondary grammar school. This paper gives an overview of the features of this competition and its task types, and analysis the quality and importance of it by statistical methods. Furthermore the role of the competition in the enrollment and in the talent management was also tested. Important question if the successful competitors will have chosen our faculty later and these students could reach better results in subsequent study than the mean. 
Ildikó Papp, Henrietta Tomán, Roland Kunkli, Marianna Zichar (Debreceni Egyetem, Hungary): Modern Technologies in Odontologist Training

In recent years, the Faculty of Dentistry University of Debrecen (UD) has taken significant steps to ensure that digital dentistry techniques become part of its specialist training and postgraduate courses. A curriculum titled "Digital Dentistry in Practice" was devised by the dental institutions of Debrecen, Budapest, and Pécs, the Faculty of Informatics UD, and Faculty of Engineering UD. This new course was launched in 2016 in an experimental fashion, because we considered it important that dentist students have at least some basic knowledge of the mathematical, physical and technological fundamentals of their IT systems. In this presentation, we would like to briefly introduce our chapters of the curriculum and to give an account of our experience in teaching them.

Árpád Horváth (Óbuda University, Alba Regia Technical Faculty): Analysis of Complex Networks Using Python Module iGraph, an eLearning Experience

The author teaches about complex networks several years. In the course he developed the students can learn not only the theory of the networks, but he can investigate networks by the IGraph package of the Python programming language. Some years ago we developed a course that can be learned by the students without he needs to travel to the tutor, and we have tried it. This article is about our observations and goals.

Dr. Piroska B. Kis, Dr. Antal Buza, (Dunaújvárosi Egyetem, Hungary): Matlab or Octave?

At University of Dunaújváros education using Matlab program package goes back more than two decades. Students are very satisfied with this software because it is relatively easy-to-use, both symbolical and numerical computations are available, and its graphics is excellent. However, besides its great number of advantageous properties it has a great drawback. Matlab in not a free of charge software nor even for education purpose. This fact is a remarkable drawback, especially from the point of view of home learning. In the recent years, Octave program package has been continuously developed. For personal use, Octave is a free of charge software. Usage of Octave is similar to that of Matlab. Observations/experiences referring to education using Matlab-Octave are going to present, it is to be hoped that the results are notable and utilizable at the education institutes. 
Ábel Garai, Attila Adamkó, István PÉntek (University of Debrecen, Department of Information Technology, Debrecen, Hungary): Case Study on Motivation in IT Education through University-Industry Telemedicine Partnership

University-industry partnerships bring value for all participating partners. In this paper are demonstrated the pros and limits of university-industry partnership and its effects on student motivation through the practical experiences of the cooperation among the University of Debrecen Department of Information Technology, Semmelweis University 2nd Pediatric Clinic and T-Systems. Educational institutions and industry partners balance their information and know-how surplus and deficit. The motivational factor on individual level is evoked through the course of filling the educational institution's technological and the industry partner's know-how gap. Industry supplies IT educational institution with actual practical examples. Meanwhile, universities deliver the scientific knowledge-base. In this paper stand two interconnected educational motivation factors in correlation with each other: Linking IT-education with medical education through interdisciplinary telemedicine field of science, and associating the information technology education with the information and communication industry. The article summarizes the positive effects and also the limits on educational development of the presented interdisciplinary university-industry partnership.

\section{Education}

Monika PogÁtsniK*, Ildikó HoliK** (*óbuda University Alba Regia Technical Faculty, Székesfehérvár, Hungary, ${ }^{* *}$ Óbuda University Budapest, Hungary): First Experiences of the Dual Educational Program in Székesfehérvár

This study is presenting an empirical research, which is about to compare the effectiveness of the students participating in the dual training and those who study the traditional way. This new model was introduced recently in the Hungarian higher education and is in focus of interest. The dual education students perform during the study period together with the normal full-time students in their higher education institute. During the corporate period the student gains a specific professional knowledge and practical working practice. 
ImRe Kocsis*, Ildikó PAPP** (*Debrecen University, Technical Faculty, Hungary, ${ }^{* *}$ Debrecen University, Faculty of Informatics, Hungary): Professional Practices for Middle School Students Orienting Toward Engineering Carrier

Workshops for secondary school students are regularly held by the staff of the Department of Basic Technical Studies (Faculty of Engineering, University of Debrecen) in six topics. These topics are related to the educational and research activity of the faculty and the content is adapted for the age and the field of interest of students. Creativity, manual activity, experiential learning and the introduction of the "engineering approach" in different situations have priority in the program, which is largely based on using our teaching experience in technical higher education. The concept of the curriculum and the reception of the programs are presented in the talk.

Edith Debrenti (Partium Christian University in Oradea, Romania): Lessons from a mathematics competition

Word problems are lifelike, practical problems in which the relation(s) between known and unknown quantities is(are) provided in a textual form, and the solution to the problem requires some kind of mathematical model. Word problems play an important role in problem solving and in developing reading comprehension skills. Teaching word problems is one of the most difficult methodological issues. The present research investigates (altogether four) word problems and their solutions on the basis of the Bihar county model $(N=636)$. The problems were designed for 4 th grade students participating in a local mathematics competition. The problems were solved by the second year teacher training majors at Partium Christian University, as well as by teacher training majors at Nyíregyháza College. This provided an opportunity to investigate students' word problem solving skills and their previous knowledge in this field and to reveal any deficiencies that need to be tackled in the future.

LÁsZló KISs (Óbuda University, Budapest Hungary): Thoughts About Teaching Mathematics, 2016

This article follows up and expands upon my earlier article titled "Thoughts about teaching mathematics, 2015". It touches upon the following questions and ideas: - What kind of structure should be used to achieve a modern way of teaching mathematics? - Connections between the way mathematics is taught and societal thinking - Correctness and incorrectness of solutions - Avoiding mechanistic thinking - Elimination of unnecessary information from teaching - Connections 
between various pieces of mathematical knowledge Included are specific examples for the above as well as for topics mentioned in the aforementioned article.

\section{Posters}

ÁrpÁd Horváth (Óbuda University, Alba Regia Technical Faculty, Székesfehérvár, Hungary): Variation of TikZ Figures and Texts Written in LATEX using ec-sorter

I have developed the program called ec-sorter, that make it possible to create test papers with several version of the exercises. This can be possible if we use some parameters in those exercises. The program uses exercises stored in plain LATEX format. The new version makes it possible to get the parameters from tables located in the text of the exercise. In this way we can change the text of a TikZ figure in the several version of the same exercise. For example in a state diagram of an automaton we can change the symbols on the arrows.

TAmás Orosz (Óbuda University, Alba Regia Technical Faculty, Székesfehérvár, Hungary): Enterprise Business Process Mapping by Means of Functional Programming

Enterprise Resource Planning, ERP, Systems, like SAP, Oracle or Microsoft Dynamics, usually applies different styles of programming due to their conventions, policies and history as well. Nowadays, all of such systems apply the Object Oriented concept in their programs. ERP Systems however should cope with an enormous number of business functionalities. Therefore, the algorithms of business processes in ERP can be easily designed by functional programming. This paper makes an analysis of a few business processes had been redesigned from object oriented programs to functional. It has been found out in many cases that functional programming resulted in more effective ERP business functionalities.

\section{List of participants}

1) Ambrusné Dr. Somogyi Kornélia, a_somogyi.kornelia@rkk.uni-obuda.hu

2) Árokszállási Eszter, arokszallasieszter@gmail.com

3) Banc Roland, rolandbanc@freemail.hu

4) Bérczi Szaniszló, bercziszani@caesar.elte.hu 
5) Budai László, budai0912@gmail.com

6) Csabina Zoltánné, csabina.zoltanne@amk. uni-obuda.hu

7) Csernusné Ádámkó Éva, adamko. eva@eng. unideb.hu

8) Debrenti Edith, edit.debrenti@gmail.com

9) Dobos Dániel, dobos.daniel@amk.uni-obuda.hu

10) Dóra Levente, Idora@unicomp.hu

11) Dr Sebestyén Dorottya, sebestyen.dora@kvk.uni-obuda.hu

12) Dr. Baják Szabolcs, bajak.szabolcs@uni-bge.hu

13) Dr. Buzáné dr. Kis Piroska, piros@uniduna.hu

14) Dr. Füvesi István, fuvesi@inf.u-szeged.hu

15) Dr. Györök György, gyorok.gyorgy@amk.uni-obuda.hu

16) Dr. Halász József, halasz.jozsef@amk .uni-obuda.hu

17) Dr. Horváth Gábor, Horvath.Gabor@uni-bge.hu

18) dr. Hudoba György, hudoba.gyorgy@amk. uni-obuda.hu

19) Dr. Kézi Csaba Gábor, kezicsaba@science.unideb.hu

20) Dr. Kispéter József, kispj@mk.u-szeged.hu

21) Dr. Molnár Sándor, Molnar.Sandor@uni-bge.hu

22) Dr. Orosz Gábor Tamás, orosz.tamas@amk.uni-obuda.hu

23) Dr. Rácz Ervin, racz.ervin@kvk.uni-obuda.hu

24) Dr. Seebauer Márta, seebauer marta@amk uni-obuda.hu

25) Dr. Szíki Gusztáv Áron, szikig@eng.unideb.hu

26) Dr. Ujvári Sándor, ujvasa@hdsnet.hu

27) Dr.Molnár-Sáska Katalin, mskatalin2013@gmail.com

28) Fülöp Csilla, fulcsilla@gmail.com

29) Garai Ábel, garai.abel@inf.unideb.hu

30) Gimesi László, gimesi@ttk.pte.hu

31) Gönye Zsuzsanna, zgonye@ttk.nyme.hu

32) Grosz Imre, grosz.imre@floppy.hu

33) Gulyás Imre, imre.gulyas@wsh.hu

34) Hatalyák Dezső, hatalyak.dezso@amk.uni-obuda.hu

35) Horváth Árpád, horvath.arpad@amk.uni-obuda.hu

36) Jenák Ildikó, jenak@ttk.pte.hu 
37) Joós Antal, joosanti@gmail.com

38) Katona János, katona.janos@ybl.szie.hu

39) Kiss Attila, akiss1122@freemail.hu

40) Kiss Éva Csilla, kicsi34@gmail.com

41) Kiss László, kiss.laszlo@rkk . uni-obuda.hu

42) Kiss Lászlóné Kamrada Bernadett, kiss113laszlo@gmail.com

43) Klincsik Mihály, klincsikm@gmail.com

44) Klingné Dr Takács Anna, Klingne.TakacsAnna@uni-bge.hu

45) Kocsis Imre, kocsisi@eng.unideb.hu

46) Kovács István Béla, kovacs.istvanbela@upcmail.hu

47) Kötél László, leslierope@gmail.com

48) Kulcsár Attila, kulcsar.attila@amk.uni-obuda.hu

49) Lázár Edit, Lazar.Edit@uni-bge.hu

50) Leitner Lászlóné, hudak64@gmail.com

51) Makó Margit, mako.margit@amk.uni-obuda.hu

52) Molnár György, molnar.gyorgy@amk.uni-obuda.hu

53) Nagy Rezső, nagy.rezso@amk.uni-obuda.hu

54) Nagyné Dr. Kondor Rita, rita@eng. unideb.hu

55) Nagyné Hajnal Éva, hajnal.eva@amk.uni-obuda.hu

56) Nemes Teréz, nemes.terez@uni-bge.hu

57) Nyirati László, nyirati.laszlo@gmail.com

58) Oláh Éva Mária, olaheva@hotmail.com

59) Papp Ildikó, papp.ildiko@inf.unideb.hu

60) Perjésiné Dr. Hámori Ildikó, perjesi@mik.pte.hu

61) Pethőné Dr. Vendel Terézia, vendel@mik.pte.hu

62) Pogátsnik Monika, pogatsnik.monika@amk.uni-obuda.hu

63) Rádai Levente, Radai.Levente@amk.uni-obuda.hu

64) Sáfár Attila, safar.attila@amk.uni-obuda.hu

65) Stonawski Tamás, stonawski@gmail.com

66) Surányi Péter, suranyi.peter@afg-pecs.hu

67) Széll Tamás, winddtom@freemail.hu

68) Talata István, talata.istvan@ybl.szie.hu 
69) Tieger Balázs, tigristibi@gmail.com

70) Tóth Attila, atoth2@ukf.sk

71) Török János, j.torokhu@gmail.hu

72) Trupka Zoltán, tzoli@datatrans.hu

73) Varga Andrea, varga.andrea@kvk.uni-obuda.hu

74) Vígné Lencsés Ágnes, vigne@freemail.hu

(Compiled by Éva Hajnal and György Hudoba) 